\title{
PALLD Gene
}

National Cancer Institute

\section{Source}

National Cancer Institute. PALLD Gene. NCI Thesaurus. Code C79791.

This gene is involved in the organization of the actin cytoskeleton. 